DePauw University

Scholarly and Creative Work from DePauw University

$1-9-2019$

\title{
Marxist Education Across the Generations: A Dialogue on Education, Time, and Transhumanism
}

Derek Ford

DePauw University, derekford@depauw.edu

Follow this and additional works at: https://scholarship.depauw.edu/educ_facpubs

Part of the Education Commons

\section{Recommended Citation}

Accepted manuscript of an article originally published in: Rikowski, G. \& Ford, D.R. "Marxist Education Across the Generations: A Dialogue on Education, Time, and Transhumanism." Postdigit Sci Educ (2019). https://doi.org/10.1007/s42438-018-0028-1 The final publication is available at: https://link.springer.com/ article/10.1007/s42438-018-0028-1

This Article is brought to you for free and open access by the Education Studies at Scholarly and Creative Work from DePauw University. It has been accepted for inclusion in Education Studies Faculty publications by an authorized administrator of Scholarly and Creative Work from DePauw University. 


\section{Marxist Education Across the Generations: A Dialogue on Education, Time, and Transhumanism}

Glenn Rikowski, University of Lincoln, London, UK, rikowskigr@aol.com

Derek R. Ford, DePauw University, Greencastle, USA, derekford@ depauw.edu

In this dialogue, two educational theorists discuss a range of topics at the nexus of Marxism and education, exploring the rich and diverse paths traversed within and around Marxist educational theory. The first part consists of a synthesis of their own trajectories and how they fit into broader social movements and political and academic conversations. In particular, they focus on the social production of labour-power and pedagogical logics. The second part concentrates on postdigital debates, including conceptions of time and transhumanism.

Glenn Rikowski is a Visiting Fellow in the College of Social Science at the University of Lincoln. In 2014-15, he was a Visiting Scholar in the Department of Education at Anglia Ruskin University. During 2001-2013, Glenn was a Senior Lecturer in Education Studies in the School of Education at the University of Northampton. Glenn was a Senior Research Fellow in Lifelong Learning at the University of Central England (1999-2001), and a Research Fellow in the School of Education, University of Birmingham (1994-1999). Prior to that, Glenn taught in further education colleges and schools in Essex and London (19851989) and at Epping Forest College (1989-1994). From 1982-85, he was a Research Officer for the City of Coventry Education Department. Glenn was a member of the Hillcole Group of Radical Left Educators from 1994-2002. With Anthony Green (UCL Institute of Education), Glenn co-founded and ran the Marxism and Education: Renewing Dialogues seminars twice-yearly from 2002-2007. Also with Anthony Green, he co-founded the world's first book series on Marxism and Education (with Palgrave Macmillan) in 2004. He has appeared on TV (BBC News 24) and BBC Radio 4.

Derek R. Ford is assistant professor of education studies at DePauw University, where he teaches classes in philosophy and history of education. His research focuses on the pedagogy of social movements and has appeared widely in journals like Cultural Politics, borderlands e-journal, and the Journal of Curriculum and Pedagogy. He's written four books, the latest of which is Politics and Pedagogy in the "Post-Truth" Era: Insurgent Philosophy and Praxis (2018). He's edited five books, including the forthcoming Learning with Lenin (Ford \& Malott, in press) and Keywords in Radical Philosophy and Education (n press). Derek is also an organizer and activist. Since 2007 he's organized with the Answer Coalition in the U.S., and in this capacity has worked on numerous anti-racist and antiimperialist campaigns. Since 2016 he's been involved with the Korean struggle. Bridging his political and intellectual work, he's involved with the working-class think tank, The Hampton Institute (www.hamptoninstitution.org), as the chair of their education department, and he's co-editor of LiberationSchool.org.

\section{About the dialogue}

In June of 2019 Derek Ford contacted Glenn Rikowski proposing a collaboration, and Glenn suggested a dialogue. After a few months of preparation, they began the dialogue over e-mail in early October. A few weeks later, Derek visited Glenn in England for five days. They finished the conversation over e-mail, completing it in December 2019.

\section{Marxist (Educational) Theory}


GLENN RIKOWSKI (GR): Like socialism in mainstream socialist thought, dialogue has to start somewhere (which is why 'socialism in one country' is not immediately a problem). Dialogue could begin with a theme, a question, a guiding thread, a provocation, or whatever. Therefore, Derek, I thought we might begin by unfolding our own intellectual paths of development for the readers. Of course, anyone's intellectual development engages with, erupts from experiences - political, social, personal, and so on. Your interview with Zane Wubbena and Curry Malott (Wubbena, Malott and Ford 2016), and my interview with Aldo Ocampo Gonzalez (Ocampo Gonzalez and Rikowski 2018) indicate how political experiences, engagements in class struggles, protests and campaigns can impact on intellectual formation - collective, as well as individual. But I am intrigued regarding how you might reflect on your own ideas, your research and theoretical work, thus far. Is it like a river - where your work has a central flow, albeit with tributaries, a waterfall or two, with perhaps a flow into the odd lake, before meandering seaward? Or is it like a web? What metaphor might you use to understand the course of your own work Derek?

DEREK R. FORD (DF): Thank you for asking this question (and for beginning this exchange with a reference to Stalin's socialism in one country policy, and later theory). For the past year I've intended (but failed) to reflect more on my past work and strengthen the intentionality of my theoretical labour going forward. Because writing is a primary way that I think, I tend to work quickly and in response to whatever philosophical and political problem I'm immersed in or struggling with. I rarely know where I'm going until I get there.

One way to conceive of my research is as a kaleidoscope. A kaleidoscope contains several reflecting and angled surfaces that bounce off each other and reflect one or a series of objects to create different and moving patterns. Crucially, the kaleidoscope needs to be held and moved and it needs a light source. The angled surfaces of my work are pedagogy (by which I mean educational modes of life and relation), revolutionary struggle, and subjectivity. These, at least so far, have always operated as the surfaces that show me the object I'm interested in. The specific objects change over time. These objects are often particular thinkers (because I'm trained as a philosopher), political issues or struggles (because I'm an organizer), or gaps, lacunae, contradictions, or other problems that I encounter in the fields I'm reading and teaching in (because I'm an academic). Over time the objects accumulate or reappear here and there.

I'll give an example from early on (for me) that can toss things back to you. During my first year in graduate school I was involved with my city's Occupy movement. At the same time I was taking classes with Don Mitchell, a Marxist geographer who would later be on my PhD committee. Occupy was in the middle of our downtown (just across from my employer actually). As we struggled against the banks, questions of space and education kept coming up. I decided to dig more into Marxist educational theory, and this is when I first encountered your work, particularly your "scorched earth" (Rikowski 1997) approach to the field. The specific objects of study at the time were Marxist educational theory, critical geography, and Occupy, and I approached them with an interest in advancing revolutionary struggle and articulating some component of pedagogy that would bear on the production of subjectivity. Graduate school was sort of a process of accumulating objects in the kaleidoscope, and the book that I produced out of my dissertation, Education and the Production of Space: Political Pedagogy, Geography, and Urban Revolution (Ford 2017) looked at these central concerns from different turns of the kaleidoscope, and each turn produced (or started to produce) new pedagogical concepts for revolutionary struggle.

In any case, how can we understand your research, which has a much deeper history and longer trajectory than mine? I'm also curious to hear about your 'Scorched Earth' article (Rikowski 1997), if you can work it in. 
GR: Ah, 'Scorched Earth'! I've had to 'explain' that article (Rikowski 1997) more times than perceived problems in all my other works put together! Many years ago, I met Paul Willis at an academic event in Dudley, and one of the first things he asked me was: why did I write 'Scorched Earth'? Cutting a long story short, in the early 1990s I decided to read and critique what I took to be 'Marxist educational theory'; or, more precisely, how educational theorists and researchers had used Marx and Marxism in their work. The two articles I produced in the mid-1990s (Rikowski 1996; Rikowski 1997) were results of this critical reading. The first article, 'Left Alone' (Rikowski 1996) explored some external threats to Marxist educational theory - which were substantial at the time - such as the 'death of Marxism' syndrome (following the demise of the Soviet Union and the Eastern Bloc), postmodernism, and others. The second article, 'Scorched Earth' (Rikowski 1997) explored internal weaknesses within Marxist educational theory. These were substantial: determinism, functionalism and a vulgar structuralism, to name a few. But, most of all, I was alarmed at the lack of reference to the writings of Karl Marx in texts of the Marxist educational writers I studied in the early 1990s. This shortcoming went right back to the classic Schooling in Capitalist America (Bowles and Gintis 1976). My response to this was a drastic one: I advocated a 'scorched earth' policy, a refusal to drive towards some cobbled-together synthesis out of material from the old Marxist educational theory, and to start out again from Marx! Ignore all the guff about 'Marx did not say much directly on education'; read Marx (not just what he says on education), and get a grasp of what makes capitalist education become distinctly capitalist education (i.e. come to an understanding of the capitalist form education takes in contemporary society), from Marx's own work. Start out from Marx: not Althusser, not Poulantzas, not Gramsci, not Bourdieu, not Bowles and Gintis, not Michael Apple, or any other theorist of education and capitalist society. Of course, in academic life starting out from scratch is seldom, if ever, advocated, and, as I found out, certainly not popular amongst Marxist educational theorists, even if it's to strike out anew from Marx!

I guess writing about 'Communist Study', in the States especially, as in your 2016 book of that name (Ford 2016), raised some problems for the Critical Pedagogy people, especially in the light of what Curry Malott (with whom you have co-written) notes regarding anti-communist tendencies within the Critical Pedagogy fraternity (see Malott 2016 and 2017). Perhaps you might comment on that, Derek. Furthermore, I would be interested in what you have to say on the relationship between Communist Study (Ford 2016) and your latest book Politics and Pedagogy in the "Post-Truth" Era (Ford 2018). Do you view the relationship as a progression in some sense; or does the new book rather fill out, expand upon, the pedagogy set out in Communist Study? Or both? And where and how does Education and the Production of Space (Ford 2017) fit into the triad?

DF: I appreciated your scorched earth provocation when I read it, and it in fact provided me with an out, a justification for side-stepping a series of looping debates I found cumbersome, overly complicated, and struggling for relevance. These were debates within Marxist and adjacent educational theories you just named, as well as others between the poststructuralist and Marxist groups. (Incidentally, by this time Peter McLaren was on my dissertation committee, and I remember him labelling your work as the most serious Marxist scholarship in education). But because I was a doctoral student, I had to prove my knowledge of these debates. The first part of Education and the Production of Space (Ford 2017) is me working through the basic tenets of critical pedagogy and McLaren's revolutionary critical pedagogy, and then trying my best to weave together insights from the latter with those from its feminist and poststructural critics. And then I basically did what you called for in 'Scorched Earth' (Rikowski 1997): I read Marx, specifically the three volumes of Capital (Marx, 1867/1967, 1892/1972, 1894/1982), for a political-subjective-economy of the 
production of space. I also had to similarly study the works of Henri Lefebvre, who was discussed in education but never in any real systemic or deep way.

Yet perhaps this is where a difference between us arises, or maybe it's just a difference from this particular provocation of yours: in order to synthesize a pedagogy for space, I had to take leave of Marx and even much of the Marx-inspired revolutionary critical pedagogy, and turn instead to Gert Biesta and Tyson Lewis. I didn't find much about pedagogy in critical pedagogy or Marxist educational theory. It is primarily structural analyses of society and educational processes, policies, and systems. It's always critiqued for not discussing classroom practices, which I don't have a problem with (although, as an aside, McLaren has several books that deal precisely with these). What I was-and am-really interested in is pedagogy, by which I mean modes of educational relationships, educational logics, and educational forms of life. The last chapter of Education and the Production of Space (Ford 2017) is really my first attempt at formulating a pedagogy in this manner, and I did so by augmenting Lefebvre's spatial triad with an educational one of learning, studying, and teaching. I think it worked well, but it was just the beginning of something.

That something is what I'm still working on, and what my last two books were about (note: Communist Study (Ford 2016) was written just after Education and the Production of Space (Ford 2017), but it was published before). Communist study looks at the relationship between subjectivity, political economy, and pedagogy. As you know, an organizing principle of Marxism is that the future only ever emerges out of the present; that there are multiple modes of production heterogeneously blocked together, and with these modes of production there are different modes of relating, or being with, together, for, and against others. To do this, I turned to Judith Butler and Karl Marx, arguing that subjectivity is performatively constituted through modes of production (for example, the language and norms of private property, the contract, the wage are norms through which we come into being). The main portion of the book articles a theory of study using Jean-François Lyotard. Although he doesn't have a great reputation in Marxist circles, I think this is because he hasn't really been read on his own terms. But in any case, Lyotard gives me a series of concepts like the secret and the figural that really help articulate studying as a process of divorcing ourselves from the present and latching onto an excessive surplus at the heart of being. He also has a fantastic and important critique of democracy. He shows how it's a form of terror that demands that we actualize ourselves by being constantly and intensively public. This helps me make studying into a partisan project, but it can't be properly communist unless its organized into the party-form.

My last book, Pedagogy and the "Post-Truth" Era (Ford 2018) picks up here, with the party-form. As you said during our bus ride back from the University of East London a few weeks ago, this book is less focused than Communist Study (Ford 2016)in that there are numerous pedagogies, rather than $a$ communist pedagogy. This has to do with the material conditions that prompted the book. Although I initially dismissed the "post-truth" talk as so much liberal hogwash, I got to thinking that maybe it's a useful terrain to intervene on. Lyotard helps me again here with his distinction between the modern and the postmodern, where the former isn't a supercession or negation of the former, but rather an interruption, excess, indivisible remainder always present within it. So the "post-truth" is an interruption of the truth, and thus a great opportunity to produce a new truth (a Marxist truth!). But in order to do this, we need to continually struggle to wrest ourselves from the dominant configuration of education, thought, being, relating, and politics. So the pedagogies I develop are all aimed at disrupting, disordering, and disorienting us away from the prevailing oppressive economic and social systems and the educational fuel on which they run. But it's also a political book, and one in which I try to reconfigure the relationship between politics and pedagogy. Usually in Marxist and critical pedagogy, pedagogy is a means to a political 
end. But for me pedagogy can't be inherently political. One can learn or study or teach a reactionary text or a progressive text, and one can't determine the outcome of any act of learning, studying, or teaching. So while politics and pedagogy overdetermine each other, there's a gap between them that has to be acknowledged, respected, and negotiated. This is why the party-form is, again, so crucial: the party organizes and provides the apparatus through which these pedagogical modes are enacted. Now, as you also said on our bus ride, I didn't make this particularly explicit in the book. I agree with that criticism, and hope that it's at least implicit in the book.

Reflecting on it now, both of these last two books have also been predicated on your scorched earth policy (Rikowski 1997), in that I've really worked with primary sources from whatever theories I'm interested in. Part of me thinks should be advocated for all of educational research. Most foundational educational research is derivative in that it reads other fields and then asks after the educational implications. After this, a second loop emerges that takes the prior readings as fact. And so it's not just Marx, but also Althusser, Gramsci, and so on who have to be read again. And we have to read the educational foundations again. This is what Malott and I did in 2015, after we finished a book project together. We went back to the founding texts of critical pedagogy, and damn were we totally disappointed. Malott's $(2016 ; 2017)$ analysis found that the whole field was ultimately a right wing, anti-communist break from revolutionary theory. And I really encourage everyone interested in politics and education to read his work on this, because it's convincing, damning, and excellent grounds to burn the whole thing down.

Speaking of which, I'd really like to hear about the Marxist educational theory-or the Marxist theory of education, how would you put it? - that you've developed in the last two decades since 'Left Alone' (Rikowski 1996) and 'Scorched Earth' (Rikowski 1997). I think there are some important convergences between my recent writing and your work on crisis and fragility that would be interesting to explore here or elsewhere. And could you also speak about how you conceptualize your overall research history?

GR: Thanks for showing how your latest three books relate Derek. In response to what you said about 'taking leave of Marx', and much of revolutionary critical pedagogy, when you turned to generating a pedagogy of space, I would not like to give the impression that I am advocating that we only read Marx! Just that, in my view, Marx must be the starting point for Marxist educational theory. I too have taken leave of Marx at certain points (only to return to reading him anew), for example, in my reading of Nietzsche, Open Marxists (e.g. Holloway, Bonefeld), the important work of Mike Neary, Paula Allman, and others on critical education, and other theorists, philosophers and researchers. I don't think we differ on that score.

Where we do differ, in my view, is on our substantive starting points and central concerns. For you, Derek, it seems that pedagogy (in its various pro-capitalist, anti-capitalist, and transformational forms) is your central interest - and this comes over strongly in your latest book and in Communist Study (Ford 2016). For me, it has been labour-power, the capacity to labour, where my work began, and is still my core interest. Pedagogy has figured little in my work; just a few nods towards and critiques of critical pedagogy notwithstanding. My concern with labour-power goes back to the mid-1970s, with the end of the post-War boom and the rise of youth unemployment in the UK. This was when schools were castigated by employers for not meeting the 'needs of industry' regarding labour-power requirements. It was this concern that motivated me to research the recruitment process for young workers, on the basis that it was in recruitment that employers gave particular attention to what they were looking for in young people making the transition from school to work. My PhD work at the University of Warwick, therefore, focused on the recruitment of craft and technician engineering apprentices in Coventry, with engineering being the obvious choice as Coventry, 
in the early 1980s when I undertook the research, had the greatest concentration of engineering employment of any UK city, and I had worked previously in an engineering factory. I undertook interviews with apprentice recruiters in 107 firms (plus 12 in a pilot study) on the criteria and methods of recruitment, and I also carried out 107 shop floor interviews with engineering craft and technician apprentices. During 1981-82, 1992-93 and 1995-96, I studied Marx, and though I was reading Marx from 1980 onwards these were the really intense periods. It was this empirical work together with the reading of Marx that moved me towards a concern with the social production of labour-power in capitalism. Of course, the social production of labour-power is not just about what happens in educational institutions: it can include training, work-based learning, and labourers can enhance their labour-power in production itself, and other institutional elements can play a role - it's not just about what happens in primary, secondary and post-compulsory education.

However, by the mid-1990s I realised that I was viewing only half the picture. Drawing on Marx's distinction between labour-power and the general class of commodities in Theories of Surplus-Value - Part 1 (Marx 1863:171), I became more interested in the incursions of the latter commodity form in educational institutions, and during the late-1990s and early 2000s I explored the 'business takeover of education' and commodification in education on the back of this. Thus, the focus from around 2000 has been on the formation of the two commodity forms, labour-power and the general class, within education. The focus on commodity forms in education also found expression in my recent work on crisis in education. I hope this addresses your question about how I conceptualise my overall research history, Derek.

In light of all this, it's problematic for me to address your question on what Marxist education theory I have developed in the last two decades since 'Left Alone' (Rikowski 1996) and 'Scorched Earth' (Rikowski 1997). This is because, as far as I am concerned, the focus has not been primarily on developing Marxist educational theory per se in my work. Indeed, I would go along with Paula Allman's view that, in a sense, there is no such intellectual entity as "Marxist educational theory", or at least there should not be as it implies "that education belongs to some separate aspect human life" and sets off theory on a vulgar structuralist track (Allman 2007: 51-52). In private conversations with Paula she indicated that it is a mode of bourgeois thought to separate out the 'political' from the 'economic' in our thinking, or the 'educational' sphere, come to that. Rather, I would want to use 'Marxist educational theory' in a very loose and general sense; as theory, research and writing where Marxists focus on education, and I think 'Left Alone' took this line in its enumeration of the forms of Marxists' engagement with education (Rikowski 1996:422-423).

But getting back to your question, Derek, and taking the previous paragraph into account, I would argue that my work on the social production of labour-power has developed Marxist educational theory in the general sense noted above. I have attempted to answer a basic question which I have been concerned (maybe obsessed) with for nearly 40 years now: what is it that makes education in capitalist society distinctly capitalist in nature? Or, slightly differently, what is the social form (its mode of existence) that education takes in capitalist society? As I have tried to indicate, the social form assumed by education in capitalist society is its reduction to labour-power productin. Thus, when Michael Apple points out, disingenuously, that people like me are reducing education to economy in thought and research, he fails to see that there is a practical reduction of education to labour-power production in contemporary educational institutions, whilst ignoring what I say about avoiding vulgar structuralism, which, for me, is a real problem in Marxist educational theory. The reduction of education in today's capitalism to labour-power production is still in its infancy, though gathering strength, especially in post-compulsory education in England. 
Recently I have addressed the issue of Marxist educational theory directly in terms of what it has to offer anti-capitalist and communist movements. Thus, my two most recent works (Rikowski 2018a and 2018b) explicitly take up the challenge advanced in 'Scorched Earth' (Rikowski 1997) (21 years after it appeared) of starting out afresh in Marxist educational theory: Rikowski (2018a) notes this autobiographical point in the opening paragraphs. However, it is through analysis of the two commodity forms (labour-power and the general class) that this renewal in Marxist educational theory is advanced in these two latest works.

Our work would ultimately meet up if I was to consider the forms of pedagogy adequate to labour-power production (that would be truly horrific) and resistances to it, and alternatives to it, and oppositional forms of pedagogy. Then we could dance to the same music! But I am way off arriving at that point.

One area that we have both engaged with is Magical Marxism - after Andy Merrifield's book (Merrifield 2011). You are clear in your latest book that Marxism often seems to lack vibrancy, spark, and magic. There is a kind of "zombie intellectualism" (Ford 2018: 3-5) in much Marxist discourse that piles up criticisms of the hard times capitalism is giving us, shows the apparently monstrous power of capital, and yet fires off exhortations regarding political struggles. All this undermines these struggles (3). Do you think that the necessary "magic" can be brought to education in state-financed and controlled educational institutions (or at least into struggles in and around those institutions), or is it only in the Party where a magical pedagogy can truly exist and thrive?

\section{Schools, education, and time}

DF: It seems clear to me that we share a common disinterest, an inattention to schools as they exist. Is this true, or is it too vulgar an articulation?

GR: Well, as I noted earlier, I am interested in education policies in terms of the business takeover of schools, and I have collected a lot of material on that, and may get round to writing from that material eventually, though it's not an immediate priority. And I am interested in the pedagogics involved in the social production of labour-power, and also in alternatives forms of education, outside mainstream schools, colleges and universities. In terms of seeing mainstream educational institutions as priority sites for radical or critical pedagogy, this becomes more difficult as capital takes hold of these institutions through commodification and marketisation. Nevertheless, I am interested in resistance to, and any reversals in these trends. What about you, Derek?

DF: For me, it doesn't mean that I don't find the school a crucial site where pedagogy takes place. And I'm actually torn about the role and future of the school in progressive politics. Part of me sympathizes with Hardt and Negri's (2000) analysis of the blurring or elimination of boundaries that isolated modern institutions like the factory, family, and school. I'm not sure if learning was ever primarily done in the school, but it's definitely the case today that learning transcends the school. On the other hand, this isn't an inherently progressive development. With lifelong learning, we're forced to constantly retool and reskill ourselves to fit the needs of global capital. Here I can imagine the school as a kind of barricade against global capital, but it obviously couldn't be in the form of a holdover from modernity and would instead have to be reimagined and reworked. This is precisely why I'm not especially interested in existing schools: education isn't confined to them, and any effort to reimagine and reshape the school as a barricade in the struggle against capital would entail a broader social struggle.

Given this, my primary object of study is the struggles of workers and oppressed peoples, and the Party is the concentration and crystallization of these struggles, the form that 
organizes and coheres them. What makes the Party magical is the affective and imaginative dispositions it engenders and depends on. For me this is most clear in the role of the Party program, which is as heartily based in the present as it is in the future. The program says who a Party is and what it wants. The program wipes away "revolution" as an abstract or flimsy concept and makes it a concrete reality: revolution means this, that, and so on. I always refer people in the U.S. to the program of the Party for Socialism and Liberation (2016) as a great example of this kind of Marxist magical thinking. When this is the centrifuge from which practical activity springs, revolution isn't projected into a future but injected into the present, making it so the present feels foreign and the future feels possible. Interestingly, when Eldridge Cleaver defected from the Black Panther Party in 1971, Huey P. Newton (2002) attributed the Party's endurance to the program. "The only reason that the Party is still in existence at this time, the only reason we have been able to survive the repression of the Party and the murder of some of our most advanced comrades, is because of the Ten-PointProgram-our survival program" (Newton 2002: 201). Newton says the program was formulated by "dreamers" who "were armed with an ideology that provided a systematic method of analysis of how best to meet those needs" (Newton 2002: 202), that ideology being Marxist-Leninism. As such, it's not that the Party is the only place where a Marxist magical pedagogy can thrive, but it's currently the place where it's thickest and ripest.

One element of this pedagogy that intrigues me is precisely the generation of an affective disposition toward the future, and thus how time is figured and enacted in the party. Here is perhaps one point where our work converges in some way. This is especially important in our current temporal configuration of postdigital time (Ford, in press). The definition of the postdigital that makes the most sense to me is an era in which technology is no longer "separate, virtual, 'other' to a 'natural' human and social life" (Jandrić et. al., 2018: 893). I think about social media and the ever-increasing rapidity with which information and knowledge, data and affect circulate. Every day on Twitter there's a new storm of outrage, concern, and debate. You try to enter it, but it moves so quickly, there's so much to learn and consider, not to mention the never-ending stream of commentary and takes. Before you feel like you've got some ground to stand on, a new series of storm fronts move in. On top of that, the technology itself develops so rapidly that there's rarely a moment of stasis like there was with, say, the introduction of the television.

We're perpetually learning to try and catch up with the present. These conditions breed horizontalism and individualism, which are detrimental to social struggles. One thing the Party does here is enable us to detach ourselves form these debates while the collective first figures out what, strategically and tactically, we need to respond to and, second, what that response will be. Then we respond as one. Of course, we have different personalities, networks, and so on. But our responses amplify a particular message that can result in an effective intervention. At LiberationSchool.org we just published an excellent piece by Ben Becker (2018) on this very issue, and I highly recommend this to all organizers and activists. Force requires collectivity, coordination, and thought, which in turn depend on time and a particular kind of detachment from postdigital time. Time is such a fundamental issue for anti-capitalists because time is so central to capitalism, given that value, the lifeblood of capital, is defined as socially necessary labour-time. Given this, I'm curious as to what your research has uncovered about social time? Is there anything in there that can help us think through this particular postdigital temporal problem?

GR: First of all, Derek, I'm not sure what the 'postdigital temporal problem' is, or means. Jandrić and his co-writers (Jandrić et. al. 2018) seem to conflate a number of developments in their definition you include above: insertions of technologies in human bodies (including chemical technologies) where they can appear as parts of us; ways in which technologies command us (from alarm clocks, to surveillance machines, cell phones, 
Facebook etc.); the ways technologies influence and shape social lives and interactions; and the bombardment of information on those who enter social media, Twitter, e-newsrooms and the like. This is all in addition to how technology is inserted into the capitalist labour process, as well as various aspects of consumption, labour-power production and reproduction yielding consequences for the real subsumption of labour. Such frenzy! I don't think it's a case of 'catching up' with all this stuff; it's impossible anyway, and attempting to do so might not be mentally healthy!

What I would be interested in is whether all these dizzying technological outpourings and incursions tell us anything about time itself. My view is that we are not in a position to say, and this is because attempts to grasp the nature of social time have hardly begun. I would make a distinction between social theories of time, which are basically sociological theories of time resting on various identities (e.g. class, gender, age etc. groupings - and these are legion) and perceptions of time flow, on the one hand, and theories of social time, the nature of time in capitalist society (capitalist time, or times), on the other. Thus: social theories of time, versus theories of social time. If you look at journals such as Time \& Society the emphasis is almost entirely on the former. However, in the last ten years or so, researchers within Marxism have made a start at theorising social time: what time is, in capitalist society (e.g. Tomba 2013; Tombozos 2014; Martineau 2016). Moishe Postone's groundbreaking Time, Labor and Social Domination (Postone 1996) provided impetus to this new work on time and temporality.

DF: But perhaps you could be a bit more specific about your own engagement with time, Glenn. How did you become interested in the topic, and more to the point, why did you want to pursue a theory of social time?

GR: Yes, I need to make that clear Derek. Well, my interest in time has autobiographical roots. My father was a watch and clock repairer, and he also made grandfather clocks and wall clocks, including their wooden cases. He was a tremendous craftsman, and had his own workshop, and I grew up in that environment. I learnt how to fix clocks, though I was not very good with watches. Noon and midnight were always big events in our house! My mother eventually persuaded my father to silence the clocks we had in the house! So I always had this practical engagement with time and timepieces, and I used this experience to win some research money, with the help of the British Horological Institute (my father and my brother were both BHI members), from The Worshipful Company of Clockmakers to explore horological training in the UK (resulting in Rikowski 1999).

But it was Time, Labor and Social Domination (Postone 1996) that sparked off my theoretical interest in time within Marxism. Discussions with Mike Neary (then at the University of Warwick) were vital to the development of my thinking on social time. We talked a lot about Postone, but also about Marx and time and the theoretical focus on time and temporality as the millennium approached, which led onto discussions about Einstein, the 'speed of life' (before Accelerationism took off) and the measurement of social time. Our thinking on socially necessary labour-time was particularly important for us in the late-1990s and early-2000s, which generated a number of works (e.g. Neary and Rikowski 2000 and 2002; Neary 2004).

For me, attempting to grasp the nature of social time in capitalism, the social form that time takes in contemporary society, starts with the analysis and critique of socially necessary labour-time. The thing with Accelerationism is that without a theory of social time the accelerationists have no way of knowing if social time is accelerating (or not), or how or why it accelerates (or slows down). They have no idea about the conditions under which social time speeds up, or slows down. I have been working on some ideas over the last couple of years that indicate what these conditions might be; it might be possible to say something about the speed of social time, and hence of social life itself. 
DF: I'm not sure if the postdigital theorists conflate all sorts of things so much as collate different phenomena-each with their own particularities, complexities, contradictions, and so on-in order to demonstrate a broader tendency. And Glenn, you're definitely right: what a frenzy! One question is if any of this is new. Marx is really interested in time and how capitalism colonises or transforms it, and how labour pushes back, struggles to make its own temporal order. Chapter 10 in the first volume of Capital (Marx, 1867/1967) is all about this, and Marx distinguishes early on there between absolute and relative time. There are absolute limits to the working day imposed by nature and class struggle, and so capital struggles to reconfigure the working day, to transform relative time, including speeding up the production process itself. If my production requirements at work increase, if I've got to teach 4 classes instead of 3 during the same time, then I've got to work faster. Time is speeding up relatively.

You are completely right to say that it's impossible to catch up - and that attempting to do so can have deleterious effects on the body, including the mind. But if we want to keep selling our labour-power we have to do our best to catch up. Applying for jobs or even applying for or renewing benefits requires that one make all sorts of accounts on all manner of online systems, of which new versions and new models come out constantly. There's never a new equilibrium achieved.

Digital technologies have intensified the extent and ease to which production processes speed up, and for me digitalisation represents a qualitative shift here. I'm not concerned with figuring out if there's an objective substance out there called time, because for me all time is socially produced, and it's clear that, at least in my context of the United States, it's speeding up, and has been significantly throughout my life. And it's not just my work, but bleeds over into my entire life. Some of this may have to do with how the labour process itself tends to bleed over into my entire life (even as I'm clicking around on the internet "for fun" I'm producing data to be sold). There are objective measures we can use to verify this. Consider how digital platforms have rapidly accelerated the rate of academic publishing. It's not that they've produced this, because there are all sorts of other factors at play. But they've definitely enabled this. If we were still mailing our manuscripts to journal offices, we wouldn't be at the rate we're at now, and if we were still getting journals mailed to us, we wouldn't be reading at the rate we are now (or, we wouldn't be expected to read at the rate we are now).

\section{Transhumanism}

GR: The focus on technology per se tends to generate ever new forms of technological determinism. This can be seen in many of the writings on transhumanism in particular, and I was wondering how you might view transhumanism, Derek. How would you avoid the double reduction of perceiving the mechanisation and technologisation of the human, on the one hand, and the humanisation of technologies (e.g. Artificial Intelligence (AI) and the development of human features, capacities and attributes within robots and other machines), on the other?

DF: Technological determinism is a danger for sure, and something to be militated against in social movements. For example, there's a tendency on (some parts of) the left to view automation as a transition to communism, which ultimately takes the class struggle out of, well, class struggle. There's no such thing as technological determinism because there isn't an autonomous sphere of life called "technology" that acts independently. Technology is produced and, like any other result of production, has its own constraining and enabling factors. The task is to ask under what conditions the technology is produced, and what conditions it enables or constrains in the contemporary mode of production, and whether 
these are desirable or not. Given the genocidal effects of humanism that persist to this day, I support efforts to denaturalize "the human" and show how the human is not a fixed or biological essence but something that is socially produced. Some forms of humanism have also had liberatory effects when deployed, for example, in anti-colonial and national liberation struggles, when oppressed groups have struggled for inclusion in the order of the human. But rather than include more beings in "the human" it makes more political sense to reconfigure, reconceptualise, or even get rid of it. This is how I always read Althusser's theoretical anti-humanism. What I'm not sure about, and perhaps you could clarify, is if transhumanism designates a period or an intellectual movement. If it's the latter, what are the movement's goals?

GR: We agree on the question of the 'human': I have no room for a transhistorical human essence either in my thinking. Your questions on transhumanism are not easy to answer, Derek. First of all, we might have to disentangle differences between a host of ideas and developments related to transhumanism, such as the posthuman. As Francesca Ferrando (2013) notes:

"Posthuman" has become an umbrella term to include (philosophical, cultural and critical) posthumanism ...[and]... transhumanism (in its variants as extropianism, liberal and democratic transhumanism, among other currents), new materialisms (a specific feminist development within the posthumanist frame), and the heterogeneous landscapes of antihumanism, posthumanities, and metahumanities. The most confused areas of signification are the ones shared by posthumanism and transhumanism. (Ferrando, 2013, p.26)

You could throw in various forms of humanism, the inhuman and inhumanism, perspectives on Marxist-Humanism, the Anthropocene / Capitalocene debate and a multitude of theories on human nature into the mix, as well.

I'm not going to sort all this out here! Ferrando (2013) does a pretty good job on some of these distinctions, and James Steinhoff's work is excellent on these issues too, especially how he links transhumanism and Marxism (see Steinhoff 2014). All I will do, for now, is to outline a few ideas drawn from my writing and thinking on transhumanism, and then address your particular points. The starting point, in my view, is not with the various technologies that are typically moved to the fore in discourses on transhumanism: AI, nanotechnology, cognitive enhancement, life-enhancing pharmaceuticals, gene editing, prosthetics, microchips in brains, and so on. These are means and expressions of the drive to constitute the transhuman as human capital. Rather, setting out from the social form of the human in capitalist society, the mode of existence of the human in capitalism provides a starting point that probes the weaknesses of capital more aggressively. Thus, as I have argued consistently for the last 20 years, it is 'human capital', the processes involved in humans becoming a form of capital that is the starting point for analysis of the transhuman.

Human capital is horrific. Initially, it was constituted by what Marx called the real subsumption of labour to capital, which primordially takes place in the capitalist labour process. The basic force of real subsumption is the action of the will of the labourer being subsumed under the dictates of capital as a form of identification. A partial identity arises between the force of capital and the labourer: the labourer socially ingests, absorbs capital's desires, its imperatives into her or his selfhood. To the extent that this occurs (it varies between individuals) then we become human capital: capital as the human. Labour-power is the gathering space for the capitalisation of the human, and human capital is the form that labour-power takes in capitalist society. 
This is a form of transhumanism, the human partially transformed into capital that is more horrific than any science fiction or contemporary science-based facts flowing from technological developments. Thus, to understand these processes, a psychology of capital, the human as capital, is required. Such a psychology has yet to be written. It would be a real psychology; the kind of psychology that Marx refers to in the Economic and Philosophic Manuscripts of 1844 (Marx 1844: 103-105). The partiality of us becoming capital is due to the fact that we are also constituted as and through labour. Thus, there is a dynamic within us (and in all aspects of capitalist society), the labour / capital relation (which can be read simultaneously as the class relation), which runs through us. The class relation is not just 'out there', in strike and protest situations, but is internal to our personhoods within capitalist society. A psychology of capital would incorporate this dynamic and transhumanism in this sense is a category of struggle.

Real subsumption has developed since Marx's time, though I would argue the capitalist labour process has never been the only site for its enforcement and incubation. Education, for example, has become involved progressively in the real subsumption of labour to capital; the incorporation of the desires and imperatives of capital within our personhoods and the bending of our wills to the dictates of capital as expressed through human representatives of capital (managers, capitalists, mainstream media operators, economic pundits, most economists, education policy makers, etc.). Ideas and education policies trading on 'employability', work-ready graduates and suchlike attest to this.

Only within this kind of framework would I then attempt to explore and analyse what is typically viewed as transhumanism - the focus on the technological, biochemical and digital developments I referred to earlier. Even then, I would add further stipulations. First, that these innovations are examined in relation to production, and especially the enhancement of the productive capacity of labour-power in its transformation into labour. Secondly, how the trans-human in capitalist society becomes transfigured as a unit of consumption in terms of bodily enhancements and modifications (which has hardly begun as yet) requires exploration. Thirdly, how these techno-developments impact on labour-power and labour market competition (e.g. taking cognitive enhancing drugs prior to examinations) should be examined. Finally, there should be analysis and critique of the commodification processes (including their marketisation, and monetisation) involved in the production and distribution of transhumanising commodities, especially those invasive of the human body. This kind of approach gets us as far away from the moralising perspective as possible; i.e. whether this or that new technology or procedure (e.g. gene editing) is 'right' or 'wrong' or 'good' or 'bad'.

But returning to your questions, Derek, the mainstream discourse on transhumanism does indeed designate a period and an intellectual movement. Taking the latter first, transhumanists such as Max More, Natasha Vita-More and Ray Kurzweil in the United States and Nick Bostrom in the UK are part of a trans-Atlantic transhumanist and posthumanist movement. The Transhumanist Declaration (first drafted in 1998) set out the principles of the movement (see Sutton 2015: 117-119). Posthumanism is a philosophy of transhumanism for these people; a philosophy that seeks to promote transhumanism, to change the world in line with a transhumanist future - where artificial evolution, evolution under the command of humanity, supersedes natural evolution. This is a "radically utopian movement, concerned with the development and application of human enhancement technologies" and "The baseline assumption is that humanity has the power to transcend its biological limitations, and that such transcendence is desirable, or even necessary for long-term survival" (Asprem 2013: 2). It is a "movement to enhance human capability and future technology" (Damayanti and Kenasri 2018: 2), which is its general goal, but specific goals include increasing the longevity of humans, eliminating diseases, and cognitive enhancement amongst many others. Some, such as Natasha Vita-More, promote the idea of designing or redeveloping human 
bodies based on choice (e.g. to have fur on our arms), which nestles nicely with a procapitalist outlook. Regarding when the movement started up, Adamczak and 55 other students at the Adam Mickiewicz University Poznan (2018) indicated that "the term transhumanism was coined in 1957 by Julian Huxley2, a British scientist, who was the "director general of UNESCO" (1), but it was in the late 1980s and the 1990s that the idea really took off. Paura traces the movement's birth to the 1980s. I provided a critique of the transhumanist movement many years ago (Rikowski 2002).

In my sense of the 'transhuman' and transhumanism - the becoming of capital within the human - this is as old as capitalism itself. However, the intensity and strength of capital within the human has grown over time. While this can be seen as a particular strength for capital, it can also be viewed as a weakness, as the capitalisation of the human becomes more obvious. Thus, we can more readily think as and through capital as the first base for a program of its destruction within and beyond us. We can think through and as capital in order to locate its weaknesses in order to destroy it before it destroys us, through either capitalist breakdown (after Rosa Luxemburg, Henryk Grossman and Robert Kurz), and / or through nuclear war, and / or climate catastrophe - or some potent mixture of these.

Though you have stated clearly your views on anti-humanism and humanism above, how would you view transhumanism Derek? And finally, perhaps you could say something about possible directions for your work flowing from your latest book (Ford 2018).

DF: Thanks for this careful parsing out of the various iterations of the transhuman, Glenn! To be honest, I don't have much to add here because I agree completely with your analysis and the political implications of it. The capitalisation of the human doesn't just concern technology or other elements of fixed capital, but just as crucially logics, impluses, and desires. The becoming capital of the human, in other words, is both a physical transformation and a pedagogical transformation. While not as a response to transhumanism, I'm interested in identifying some of these educational logics and seeing how they can be harnessed for a project against capital.

At this moment, I'm particularly interested in the logic of the test. Testing has a terrible rap today because we associate it only with high-stakes standardized exams. Yet testing has a more general logic or ontology to it, and we embrace all kinds of testing in our lives. We test ourselves, our friendships, our loves, our political organizations, and so on. In fact, why have politics if not to test them? One of my next projects is an examination of how the Bolsheviks used the test in their struggle for power and once they assumed state power. They viewed almost everything as a test, and Lenin explicitly talked about real tests, by which he means tests that are totally out of the Party and state's control. The real test is proctored by the masses. This represents the radical anti-elitism of Leninism and exemplifies the innovative drive of the Bolshevik project. Next, I'd like to see how testing shows up through protest movements. I hope to do some archival research next fall and also interview some leaders of the movement against the Iraq War in the U.S., which brought the greatest number of people out into the streets for anti-war demonstrations in the nation's entire history. I'd like to see if and how testing showed up throughout this process. How were the organizations and leaders tested? Were the masses tested? How about the government or police forces? Were these explicit or implicit? How might thinking about testing help us advance protest struggles into social movements?

Another project relates to a January 2019 winter term course I'm teaching titled (North) Korea in Japan: Colonialism and Education. When Japan colonized Korea in the early 1900s, they brought hundreds of thousands of Koreans to Japan as slaves. Still today there is a large ethnically Korean population, and many of them are now citizens of the Democratic People's Republic of Korea (DPRK, or North Korea). They suffer a lot of racism and repression for their citizenship status, and they could at any time give it up for Japanese 
citizenship, which comes with a lot of perks. But they keep their citizenship. They have their own primary and secondary schools, a university, and other cultural institutions (including a Buddhist Monastery) that are all managed through Chongryon, or the General Association of Korean Residents in Japan. My students and I will be the first U.S. delegation to visit Chongryon to dialogue with students, teachers, administrators, and other North Koreans there. This is an incredibly important example of how education is used to resist colonialism, and one that's basically unheard of in educational communities in the West (and throughout Asia too). So in addition to the people-to-people exchanges I'm coordinating and the on-theground organizing, I'm also interested in generalizing these lessons and experiences into some theoretical writing. correct?

And how about you, Glenn? I think you have some book projects in the works, is that

GR: Exciting stuff for you on the horizon! That's right Derek. I've been working on a series of presentations, papers and articles for the past five years on 'Crisis and Education'. In 2019, I will concentrate on turning this work into a book with that title. After that, I have some ideas for two books on labour-power, turning 40 years' research and writing on that topic into substantial works.

It's been great doing this dialogue with you, Derek. I feel that we have clarified our understandings or each other's work and our own work too!

DF: I'm very much looking forward to your upcoming books and think they will be an important contribution to the left both in academia and in the streets. One thing I've always appreciated about your thinking is precisely how careful and precise it is, and these qualities are, maybe ironically, not common enough in education. I've learned so much from you since I started my study of education in 2011 right through this dialogue. I really believe we're in an important historical moment, where Marxism is on the rise across the globe as are struggles to combat the privatization of education and reshape education for a different future. My hope is that this dialogue can serve as an entry point for those who find themselves thinking and acting within this juncture.

\section{References}

Adamczak, Z and 55 Other Students at Adam Mickiewicz University Poznan (2018) We Do Not Like It: A Likert-Type Scale Survey on the Attitudes of a young Population towards the Transhumanistic Theory of Education, On_education: Journal for Research and Debate, 1(2).

Allman, P. (2007) On Marx: An Introduction to the Revolutionary Intellect of Karl Marx. Rotterdam: Sense Publishers.

Asprem, E. (2013) The Magus of Silicon Valley: Ray Kurzweil's Transhumanism as Contemporary Esotericism. A paper presented at the European Society for the Study of Western Esotericism Fourth International Conference, 'Western Esotericism and Health', University of Gothenburg, 26 - 29 June.

Becker, B. (2018). Social media and democratic centralism: Opportunities and challenges. Liberation School, available at http://liberationschool.org/social-media-anddemocratic-centralism-opportunities-and-challenges/ [Retrieved on 17 November 2018).

Bowles, S. and Gintis, H. (1976) Schooling in Capitalist America: Educational reform and the contradictions of economic life. London: Routledge \& Kegan Paul.

Crary, J. (2013). 24/7: Late Capitalism and the Ends of Sleep. New York: Verso.

Damayanti, L. and Kenasri, P. (2018) Transhumanism Movement: The Ethics of the Future Human Transformation. Center for Digital Society, Case Study Series \#27. 
Ferrando, F. (2013) Posthumanism, Transhumanism, Antihumanism, Metahumanism, and New Materialism: Differences and Relations. Existenz: An International Journal in Philosophy, Religion, Politics, and the Arts, 8(20), 26-32.

Ford, D.R. (2016) Communist Study: Education for the Commons, Lanham MD: Lexington Books.

Ford, D.R. (2017). Education and the Production of Space: Political Pedagogy, Geography, and Urban Revolution. New York: Routledge.

Ford, D.R. (2018) Politics and Pedagogy in the "Post-Truth" Era: Insurgent Philosophy and Praxis. London: Bloomsbury Academic.

Ford, D.R. (2018). Pedagogy of the "not:" Negation, exodus, and postdigital temporal regimes. Postdigital Science and Education, 1(1). https://doi.org/10.1007/s42438-018-0009$\underline{4}$.

Ford, D.R. (Ed.) (in press). Keywords in radical philosophy and education: Common concepts for contemporary movements. London: Brill-Sense.

Jandrić, P., Knox, J., Besley, T., Ryberg, T., Suoranta, J., \& Hayes, S. (2018). Postdigital science and education. Educational Philosophy and Theory, 50(10), 893-899.

https://doi.org/10.1080/00131857.2018.1454000.

Malott, C. (2016) History and Education: Engaging the Global Class War. New York: Peter Lang.

Malott, C. (2017) In Defense of Communism: Against Critical Pedagogy, Capitalism, and Trump, Critical Education, 8(1), online at: http://ices.library.ubc.ca/index.php/criticaled/issue/view/182581 [Retrieved 20 October 2018].

Malott, C., \& Ford, D.R. (in press). Learning with Lenin: Selected works on education and revolution. Charlotte: Information Age Publishing.

Martineau, J. (2016) Time, Capitalism and Alienation: A Socio-Historical Inquiry into the Making of Modern Time. Chicago IL: Haymarket Books.

Marx, K. (1844) [1977] Economic and Philosophic Manuscripts of 1844. Moscow: Progress Publishers. Wishart.

Marx, K. (1863) [1969] Theories of Surplus Value - Part 1. London: Lawrence \& Marx, K. (1867)_[1967]. Capital: A Critique of Political Economy (vol. 1), trans. S. Moore.

New York: International Publishers.

Marx, K. (1892) [1972]. Capital: A Critique of Political Economy (vol. 2), trans. D.

Fernbach. New York: Penguin Books and New Left Review.

Marx, K. (1894) [1981]. Capital: A Critique of Political Economy (vol. 3), trans. D.

Fernbach. New York: Penguin Books and New Left Review.

Merrifield, A. (2011) Magical Marxism: Subversive Politics and the Imagination. London: Pluto Press.

Neary, M. (2004) Travels in Moishe Postone's Social Universe: A Contribution to a Critique of Political Cosmology. Historical Materialism: Research in Critical Marxist Theory. 12(3), 239 - 260. https://doi.org/10.1163/1569206042601792.

Neary, M. and Rikowski, G (2000) The Speed of Life: The significance of Karl Marx's concept of socially necessary labour-time. A paper presented at the British Sociological 
Association Annual Conference, 2000, 'Making Time - Marking Time', University of York, 17-20 April.

Neary, M. and Rikowski, G. (2002) Time and Speed in the Social Universe of Capital. In: G. Crow and S. Heath (eds.) Social Conceptions of Time: Structure and Process in Work and Everyday Life. Basingstoke: Palgrave Macmillan.

Newton, H.P. (2002). The Huey P. Newton Reader, ed. D. Hilliard \& D. Weise. New York: Seven Stories Press.

Ocampo Gonzalez, A. and G. Rikowski (2018) Interview on Marxism, Critical Pedagogy and Inclusive Education: Discussions for a Revolutionary Discourse (Glenn Rikowski interviewed by Aldo Ocampo Gonzalez), The Center for Latin American Studies on Inclusive Education (CELEI), Santiago, Chile, March, online at: https://www.celei.cl/wpcontent/uploads/2018/03/Entrevista-sobre-Marximo-Pedagog\%C3\%ADa-Cr\%C3\%ADtica-yEducaci\%C3\%B3n-Inclusiva_Dr.-Glenn-Rikowski_UK.pdf [Retrieved 4 July 2018].

Party for Socialism and Liberation. (2016). Program of the Party for Socialism and Liberation. Liberation School, online at http://liberationschool.org/program-of-the-party-forsocialism-and-liberation/ [Retrieved 17 November 2018].

Paura, R. (2016) Singularity believers and the new utopia of transhumanism, Im@go: A Journal of the Social Imaginary, 5(7), pp.23-55.

Postone, M. (1996) Time, Labor and Social Domination: A reinterpretation of Marx's critical theory. Cambridge: Cambridge University Press.

Rikowski, G. (1996) Left Alone: end time for Marxist educational theory? British Journal of Sociology of Education, 17(4) (December), 415-451.

Rikowski, G. (1997) Scorched Earth: prelude to rebuilding Marxist educational theory, British Journal of Sociology of Education, 18(4) (December), 551-574.

Rikowski, G. (1999) The Current State of the Horological Industry in the British Isles. London \& Birmingham: The Worshipful Company of Clockmakers \& The University of Birmingham.

Rikowski, G. (2002) Education, Capital and the Transhuman. In D. Hill, P. McLaren, M. Cole \& G. Rikowski (eds.) Marxism Against Postmodernism in Educational Theory. Lanham MD: Lexington Books.

Rikowski, G. (2018a) Marxism and Education: Fragility, Crisis, Critique, Negativity, and Social Form(s). A paper presented at the International Conference on Critical Education VIII, University of East London, Stratford Campus, 25 - 28 July 2018. Available online at: https://www.academia.edu/37095004/Marxism_and_Education_Fragility_Crisis_Critique_Ne gativity_and_Social_Form_s_[Retrieved 4 October 2018].

Rikowski, G. (2018b) Marxism and Education: Fragility, Crisis, Critique. Cadernos do GPOSSHE On-line, 1(1), 142-170.

Steinhoff, J. (2014) Transhumanism and Marxism: Philosophical Connections, Journal of Evolution \& Technology, 24(2) (May).

Sutton, A. (2015) Transhumanism: A New Kind of Promethean Hubris, The New Bioethics: A Multidisciplinary Journal of Biotechnology and the Body, 21(2), 117-127. https://doi.org/10.1179/2050287715Z.00000000060.

Tomba, M. (2013) Marx's Temporalities. Trans. P. Thomas and S. Farris. Chicago IL: Haymarket Books.

Tombazos, S. (2014) Time in Marx: The Categories of Time in Marx's 'Capital'. Chicago IL: Haymarket Books.

Wubbena, Z., Malott, C. and D. Ford (2016) Becoming Through Revolutionary Pedagogy: An Interview with Curry Malott and Derek R. Ford, Journal for Critical Education Policy Studies, 14(1), 1-16. 